\title{
Dramaturgia sonoro-acústica em espaços cinemáticos $^{1}$
}

\section{Sound-acoustic dramaturgy in cinematic spaces}

Irene de Araújo Machado

Universidade de São Paulo (USP)

<irenemac@uol.com.br>

\section{Como citar este artigo (How to cite this article):}

MACHADO, Irene de Araújo. Dramaturgia sonoro-acústica em espaços cinemáticos. Revista Famecos, Porto Alegre, v. 25, n. 2, p. 1-18, maio, junho, julho e agosto de 2018: ID28545.

DOI: http://dx.doi.org/10.15448/1980-3729.2018.2.28545.

\section{RESUMO}

O ensaio investiga as propriedades espaciais das imagens audiovisuais, a partir da transdução da luz em dramaturgias fílmicas sonoro-acústicas. Contribui para os estudos dos dispositivos construtivos da cinemática audiovisual, cujo objetivo é problematizar a experiência fílmica produzida pelas imagens eletrônico-digitais. Para isso, toma como metodologia a análise semiótica de filmes que resultem em modelos críticos da concepção de cinema como base da cultura audiovisual.

Palavras-chave: Espaço cinemático. Transdução da luz. Dramaturgia audiovisual

\begin{abstract}
The essay investigates the spatial properties of audiovisual images, produced by the transduction of light in sound and acoustic film dramaturgies. It contributes to the study of the constructive devices of the audiovisual cinematic, whose objective is to problematize the filmic experience produced by electronic-digital images. For this, it takes as methodology the semiotic analysis of films that result in critical models of the cinema conception as basis of the audiovisual culture.
\end{abstract}

Keywords: Cinematic Space. Transduction of light. Audiovisua dramaturgy

\section{Introdução}

O presente ensaio resulta de indagações advindas de duas preocupações analíticas: a que indaga sobre a constituição do espaço audiovisual cinemático e a que examina a composição das imagens dimensionadas nesse espaço a partir das formas luminosas transformadas em tomadas fotográficas, reprodução animada de imagens visuais e produção sonora. Se, por um lado, trata-se de

1 Pesquisa financiada por CNPq. 
compreender a natureza do espaço cinemático em contexto de transformação da cultura visual em cultura audiovisual, por outro, objetiva-se examinar a atuação dos processos audiovisuais no desenvolvimento de uma dramaturgia que nasce no interior dos meios de comunicação impulsionados pela escalada eletro-eletrônica e digital.

Nesse sentido, a análise fílmica constitui um caminho explicativo a respeito não apenas do caráter da cultura audiovisual, como também dos elementos, meios e processos de transformação dos sistemas de signos que sustentam a configuração de um novo ambiente cultural e de um modo de perceber o espaço a partir do dimensionamento das formas luminosas. Um espaço cujo embrião são os planos de luz em sua dupla configuração visual e vibratória objeto primordial desse estudo.

Em vez de partir da premissa já consensuada que define a audiovisualidade como produto da conjugação imagem e som, partiu-se da questão: Como as imagens audiovisuais criam espaço no cinema? Ao se indagar sobre o modus operandi do sistema tecnológico, surgiram possibilidades que, se não questionam diretamente os constituintes da equação som + imagem = audiovisual, certamente subvertem a primazia da operação de adição conjugada na palavra. Duvidando de que a terminologia pudesse esgotar o entendimento do fenômeno da audiovisualidade, tomou-se o espaço cinemático para além da captura da luz como registro referencial e ponderou-se a respeito de seu desdobramento em projeção de sinais luminosos de imagens animadas. "Em movimento", a luz mostra-se como onda e não apenas como foco que incide sobre superfícies, objetos, pessoas e paisagens. Cria-se, pois, um ambiente de vibração que M. McLuhan (1975; 1996) denominou "espaço acústico ressonante". Nesse ambiente, a noção de audiovisualidade é subvertida: em vez de somatória de som e imagem, passa a ser vibração de som e visualidade na projeção da luz. Entende-se, portanto, que a informação elétrica dimensiona o espaço ressonante em que a vibração constitui uma outra ordem de fenômenos transformados em códigos culturais. No cinema, abre-se um campo de possibilidades em que a dramaturgia audiovisual explora o campo da vibração sonora como esfera produtiva de imagens, como se espera apresentar ao longo desse estudo.

\section{Ambiente e espaço audiovisual ressonante: um marco do cinema brasileiro}

Sabe-se que as imagens visuais, tanto na pintura, quanto na fotografia, constroem espacialidades a partir da noção de perspectiva óptica. Contudo, o desenvolvimento de meios eletrônicos como cinema, televisão e vídeo, 
introduziu nesse cenário outro tipo de imagem graças à transdução da luz elétrica em imagens animadas e sonoro-acústicas.

Transdução não é uma simples metáfora do entendimento semiótico. Procede do campo da eletricidade e designa os processos de transferência de energia operada por um transdutor capaz de transformar uma forma de energia em algo totalmente distinto (Seiça, 2017). Na comunicação, a transdução aplicase ao âmbito da transformação da informação pelos meios que transformam input em output com alteração radical na natureza do fenômeno (Sebeok, 1997). O entendimento aqui formulado situa o cinematógrafo como um transdutor que, ao projetar a luz capturada fotoquimicamente, configura eletricamente formas luminosas de movimento e som. Situa-se, pois, no alinhamento dos transdutores aprimorados pelas tecnologias de reprodução do som que, segundo Sterne (2003) são marcadas pela compreensão do próprio ouvido como transdutor.

Nesse sentido, o espaço audiovisual do cinema se revela como um ambiente de ressonância cinética que subverte a dominante conceitual que limita a noção de espaço apenas às coordenadas visuais posicionadas em lugares. Além de ubíquas e multidirecionais, as vibrações são produzidas em feixes redimensionando o sensório da experiência audiovisual. Configura-se aí, uma outra dimensão do espaço que convida à participação, seja pelos sentidos, seja pela consciência, em circuitos de reverberação daquilo que acontece na tela e toca corpos e mentes. Nele as formações luminosas e acústicas organizam uma outra dimensão plástica que se oferece como dramaturgia audiovisual orientada pelas elaborações sonoro-acústicas.

A cinematografia brasileira deve a Rogério Sganzerla a realização de um filme que se tornou emblemático na criação sonora como expressão plástica e dramatúrgica da audiovisualidade do cinema. Em seu O bandido da luz vermelha (Brasil, 1968), a dramaturgia sonora da voz radiofônica, dos ruídos, dos monólogos reproduzidos sob forma de um discurso interior difuso, pontuados por assonâncias e dissonâncias musicais, condicionam as ações desenroladas no plano visual. Como não se trata de meros efeitos, a dramaturgia sonora assim explorada, libera a imagem acústica de ser apenas submissa à visualidade e mostra seu potencial na qualificação da imagem, como entende Jean-Claude Bernardet $(1990 ; 2010)$ que não hesita em classificar O bandido como filme pioneiro da criação do universo sonoro como potência da imagem audiovisual (Bernardet, 2010). Ao qualificar os ruídos como actantes dramáticos, e não como mera ilustração da imagem visual, O bandido se consagra como marco renovador da relação plástica entre imagem visual e ruído, gerando, por conseguinte, experiências estéticas audiovisuais tanto de criação, quanto de crítica. 
Mais do que uma combinatória de gêneros em diferentes meios, o filme de Sganzerla se articula dialogicamente ao ambiente sonoplástico no qual se desdobra a ação narrativa. Assiste-se na tela uma inventiva enunciação de notícias emitidas pelo dueto da locução feminina e masculina da Rádio Continental de Itapecerica da Serra. As locuções são pontuadas por entoações dramáticas acompanhadas por músicas e atravessadas por frequências de outras ondas radiofônicas. Muito do que se enuncia é recortado sob forma de frases projetados num painel luminoso que enunciava notícias no prédio do então jornal paulistano Diário Popular. O que se ouve não é um simples noticiário, mas a performance dos conglomerados de barulhos capazes de revelar as coordenadas do espaço físico urbano - a região da cidade de São Paulo conhecida por Boca do Lixo, abrigo de distribuidoras de filmes, de cinemas, casas de jogos, de prostituição e de tráfico de drogas. O noticiário sobre assaltos, mortes e perseguições compõe com o letreiro luminoso que projeta frases e com as cenas do filme, todo um cenário de um espetáculo grotesco na linha de uma sátira popularesca e perturbadora. As transmissões radiofônicas embaralhadas pela diversidade de discursos e de frequências sustentam as condições ambientais da narrativa fílmica.

É como personagem principal dos acontecimentos trágicos anunciados pelo noticiário que o protagonista do filme é apresentado. $O$ bandido mascarado que usava uma lanterna em seus assaltos foi inspirado em João Acácio, famoso assaltante que atuou em São Paulo nos anos de 1960, confundindo a polícia a respeito de sua identidade, tema analisado em profundidade por Bernardet (1990). Graças às metamorfoses de sua aparência, numa época em que imagens fotográficas não expunham as pessoas à exaustão, o bandido circulava pelas ruas da cidade sem despertar suspeita nem mesmo da polícia: tanto encontrálo, quanto reconhecê-lo, parecia uma missão impossível. O bandido era a encarnação de muitos embaralhamentos que a dramaturgia sonoro-acústica explora às últimas consequências. Nesse quase anonimato, sua figura se deixa conduzir pelo aspecto contido de sua figura e o tom monocórdico de sua voz. Sua fala é sempre interiorizada em sussurros, contrasta com o som carregado e estridente da sonoplastia e, quase se apaga quando encadeada pela locução com entonações enfáticas dos locutores e das músicas reproduzidas com todo tipo de interferência sonora.

Assim como as ondas radiofônicas que parecem absorver tudo o que encontra no campo de sua frequência, as imagens fílmicas progridem agregando uma diversidade de eventos. Uma cena exemplar dessa realização acontece quando o bandido toma cachaça em um bar da Boca do Lixo. O que se ouve na faixa sonora são emissões de uma rádio francesa que atravessam a locução 
da rádio brasileira por uns segundos. Enquanto ouve-se a música invadida pela fala, a câmera se desloca num travelling pelas ruas e reproduz imagens visuais da mesma qualidade, com atravessamentos de luz, sombras e apagamentos. Passa por um estacionamento, focaliza cartazes de um cinema local, até que a locução cede lugar a um discurso interior, quase sussurrante, do bandido que diz:

Nesse país o cara tem que ser grosso para ser forte. Ouvi isso naquele bang-bang italiano $\mathrm{O}$ gringo. $\mathrm{O}$ cara era grosso pra burro: batia nas mulheres, cuspia, matava todo mundo. Em vez de reagir, achavam o máximo. Aí então eu vi: o negócio é ser grosso (Sganzerla, 1968, $\left.33^{\prime \prime} 49^{\prime}-35^{\prime \prime} 05^{\prime}\right)$.

A fala do bandido afirma um discurso que nem sempre é sua enunciação, mas pode ser citação da fala de outro, o que mostra que a multiplicidade de sua identidade, resvala para vários segmentos de sua ação.

O jogo de cenas e de sonoplastias oscilando entre visibilidade e invisibilidade, audibilidade e inaudibilidade, explicitam conflitos de natureza espacial. Isso é o que acontece na performance acusmática ${ }^{2}$ das vozes que enunciam monólogos de um tenso discurso interior que se presume enunciado pelo bandido, ainda que não se possa ver onde ele se situa no espaço das cenas. O processo criativo que se observa nesse jogo de invisibilidades, ganha coerência quando pensado no campo da ação da identidade do bandido, o que se questiona em uma das cenas (Sganzerla, 1968, 51"33') em que a locução radiofônica da voz masculina pergunta: "Luz vermelha, qual é o seu jogo, pistoleiro mascarado?". O bandido está dentro de um carro parado na praia sentado com sua namorada Janete Jane. A câmera em travelling circunda o carro em várias voltas. O que se ouve é uma resposta do bandido à pergunta da locutora; mas o que se vê é o bandido respondendo para Janete: "Não tenho jogo". Ao que Janete replica: "O que você quer da vida?" E ele responde: "Da vida não quero nada. Antigamente eu queria ser grande". E Janete questiona: "Grande pra que?" E ele responde: “Grande, sei lá pra que: queria ser famoso, ser o bacana por bem ou por mal. Mas agora já sei que eu sou um coitado. Não sou nada." O discurso continua, mas não mais como diálogo de interlocução e sim, como discurso interior. O bandido sai do carro e caminha para a praia:

2 Um som acusmático é aquele que se ouve independente da fonte emissora (Chion, 1996; Schaffer, 1967). 
Claro que vou me destruir. Sozinho é ridículo. A gente não pode fazer nada. Meu negócio era o poder. Quando a gente não pode fazer nada a gente avacalha. Avacalha e se esculhamba (Sganzerla, 1968, 51"33'$\left.52^{\prime \prime} 39^{\prime}\right)$.

No plano seguinte ele já está no carro, fumando, com Janete.

O tom discursivo oscila entre a espetacularização do jogral dos locutores radiofônicos para os tons monocórdicos da fala do bandido em um discurso interior, ora de revolta, de escárnio, ora de melancolia. O mesmo se pode dizer com a miscelânea sonora da sonoplastia e da trilha musical que vai das guarânias da fronteira, à música das salas de concerto, sem deixar de lado os sucessos da parada musical. Na segunda vez em que o primeiro movimento da $5^{\text {a }}$ sinfonia de Beethoven (1:00"41') é sonorizado, o bandido espreita Janete pela janela de um quarto na Boca do Lixo. A moça se aproxima de Lucho, cafetão da quadrilha Mão Negra. Quando ela sobe para o apartamento, o bandido a interroga sobre dinheiro, desentendem-se e ele a expulsa.

Segue-se outra cena que marcaria a performance da dramaturgia sonora do filme. Primeiro Janete rasga as roupas do armário, depois vai para o carro estacionado em um terreno largo e vazio, abre a capota e começa a arremessar as coisas entulhadas no porta-malas ao som de uma locução performática.

Locutor: No seu desespero por não ter conseguido arrancar o que desejava, mais tutu, tenta roubar.

Locutora: Jorginho. E afinal descobre sua verdadeira identidade. $\mathrm{O}$ bandido da máscara negra ou da luz vermelha o popular homem mascarado

Locutor: Sete nomes diferentes inclusive Ari Galante, falso industrial, Jorge Vargas, falso vendedor de livros, Peres Prado, falso fazendeiro do Rio Grande

Locutora: ex garçon em Campo Grande

Locutor: ex corretor

Locutora: ex vendedor de cortador de unha na avenida São João

Locutor: ex porteiro de cinema de terceira classe

Locutora: ex bancário no Acre

Locutor: o bandido mascarado é primo de mineirinho e afilhado de Dom Helder Câmera (Sganzerla, 1968,1:01"30'-1:32"21').

Se na dramaturgia a representação se alimenta de todo um conflito de diferentes enunciados, não é difícil dimensionar que o hibridismo da composição não equaciona uma soma - de som mais imagem, ou de cinema mais rádio - como geralmente se define o processo audiovisual. Estamos aqui 
diante de uma bem articulada trama de planos em dissonância de texturas, timbres e ritmos formando um gradiente em que a presença da voz se articula mesmo na ausência do corpo, em que a visibilidade do corpo não identifica a pessoa. Uma experiência estética audiovisual que não mede esforços para ampliar a percepção pelo confronto, pelo choque, que está longe de se limitar aos espaços decadentes da Boca do Lixo e de toda a produção audiovisual que neles escoa sob o signo da marginalidade. Tem-se aqui, um forte argumento a livrar o hibridismo dos limites da soma e o espaço dos limites do visível e da presença. Afinal, no cinema, a presença do som não implica visibilidade, como se pode observar na exploração dos sons acusmáticos - índices fundamentais das imagens no espaço acústico ressonante. Tampouco se pode dizer que os ruídos que a tudo absorve e a tudo se mistura, não criam novas relações acústicas que tem o poder, não só de definir espacialidades, como também de criação de elos com o entorno.

Após explorar o caminho analítico da dramaturgia sonora aqui formulado com base na proposta de Jean-Claude Bernardet (1990), foi possível perceber como a dramaturgia sonoro-acústica das imagens audiovisuais se ampliou e enriqueceu naquilo que ela tem de mais ousado: a criação do espaço de fluxo, em que o posicionamento cede lugar à multidirecionalidade e às relações transversais e transtemporais, capazes de produzir metanarrativas e incorporar o processo perceptual e cognitivo do espectador ao processo dialógico do filme. Metanarrativa que o filme Terra sonâmbula (2010) de Teresa Prata realiza em um outro experimento de dramaturgia audiovisual.

\section{Dramaturgia sonora da memória em metanarrativas}

Apesar das evidentes imagens dos traumas de guerra que proliferam em termos de memórias visuais de cenas trágicas, com derramamento de sangue, mutilação de corpos, destruição de cidades, as imagens sonoras de estrondos explosivos, de gritos e de desespero marcam a construção dramática dos episódios bélicos. Na experiência fílmica da cineasta Teresa Prata, apesar do cenário devastado pela guerra, com a presença de corpos carbonizados e minas subterrâneas explosivas, o estopim da imagem sonora que desencadeia a narrativa é de outra natureza: o solo africano recém saído da guerra de Moçambique que assolou o país por 15 anos - tema do romance homônimo de Mia Couto no qual o filme se baseou.

No filme, a história é tematizada no trauma, na busca pela identidade perdida e na capacidade criativo-poética da memória. Tudo concentrado no 
poder expressivo da imagem acústica tecida a partir da sutileza de uma memória sonora que ganha dimensão plástica ao ser explorada audiovisualmente.

Logo na sua sequência inicial, o filme coloca os espectadores em contato com o cenário de sua escrita cinemático-audiovisual. Nela, um menino se desloca juntamente com um homem em uma paisagem seca. Seu nome é Muidinga, sobrevivente dos ataques à sua aldeia. Embora tenha perdido a memória de sua vida anterior e de sua própria identidade, Muidinga foi salvo por Tuahir, o homem a quem acompanha e que também lhe dera o nome atual, uma vez que, até sua identificação de batismo lhe fora apagada da mente. No deslocamento, Muidinga carrega uma sacola de tecido e empurra um brinquedo: um barquinho de madeira com rodinhas sustentadas por uma haste de arame. Ainda que seus passos entrem em atrito com a terra e o mato secos, em sua mente o que ele ouve é o barulho do mar. Essa memória é tudo o que Ihe restou: o sonar de ondas do mar que é tão ambíguo para ele, quanto para quem assiste ao filme, uma vez que, o barulho se confunde, ora com o vento na folhagem seca, ora com o atrito dos pés na areia.

Com isso se coloca, desde o início, aquela que será sua busca: a luta por reaver sua identidade e recuperar sua memória, o que ele acredita ser possível alcançar se ele desvendar o barulho que ressoa em sua cabeça, que tanto o deixa confuso, quanto o lança para a aventura em busca de um sonho impossível. Ao acompanhar o fio de sua exploração dessa memória acústica, também os espectadores são deslocados entre sua fuga da terra seca, dos corpos sem vida e a busca pela aventura que lhe sugere o barulho do mar. O objeto mágico de realização de seu desejo está em suas mãos, embora ali, naquela paisagem ressecada, ele seja apenas e tão-somente um brinquedo utópico, completamente estrangeiro.

O sonar das ondas que as imagens visuais traduzem em sensorialidade acústica e tátil, reproduzem aqui um som acusmático que será explorado em outros momentos da trama, quando da criação de espaços imaginados e imaginários capazes até de se aproximar das regiões de intraduzibilidade da memória. Por mais que o som se faça presença e ocupe o espaço, sua dimensão semiótica nem sempre é alcançada com facilidade, visto que nem tudo nela é traduzido visualmente. Muidinga sabe pouca coisa, mas tem certeza de que este é o grande desafio a ser vencido. "E o som do mar que eu oiço?. Eu preciso entender o que ele significa" (Prata, 2010, 38"47'-38"59'), repete insistentemente. Em experiências como essas, nem tudo é familiar; é como se os personagens interagissem em um universo estrangeiro em que a comunicação mais elementar escapa, uma vez que, os participantes da interação conversam cada um usando sua própria linguagem. 
A experiência acústica que perturba o garoto não se limita a uma articulação narrativa do argumento fílmico, pelo contrário, sintetiza um princípio de organização estética do filme. Assim como o sonar das ondas reverberam na paisagem seca da mata, a trama explora uma confluência de gêneros: cinema e literatura; ficção e documentário; comunicação e espaço; luta armada e poesia; realismo e magia; leitura literária e narrativa fílmica; escrita literária e escrita audiovisual. Explora assim, encontros entre diferentes códigos culturais. É isso que é possível acompanhar na aventura de Muidinga, em sua luta para entender o significado do sonar das ondas em sua cabeça. Trata-se de uma aventura que complexifica a própria narrativa, que joga com procedimentos da metanarrativa a saber: a metalinguagem e metalepses como se pode ler na sequência.

No romance Terra sonâmbula de Mia Couto a trama é tecida com a alternância de duas narrativas: a história de Muidinga/Tuahir, e as memórias relatadas nos cadernos de Kindzu. Trata-se de uma narrativa de encaixe entre o passado no presente, com mutualidade de relações, uma vez que a narrativa de Kindzu não apenas interfere no andamento das ações no tempo presente, como também, as ocorrências dispersas do passado formam um outro encadeamento a partir do presente. A noção de uma história dentro da outra foi mantida no filme, enquanto que os entrelaçamentos dos episódios foram alterados em função do espaço, este sim, a fonte da transposição audiovisual, quando o tempo escoa pelos espaços e transforma os acontecimentos que nele ocorrem em tramas que, por sua vez, se entrelaçam em algum ponto.

Assim, o ônibus, a estrada, a mata, o brinquedo, os cadernos, a aldeia, o navio e o rio são os lugares desse espaço transversalizado - nichos dos conflitos vivenciados pelos personagens: Tuahir e Muidinga; Kindzu, seus familiares e vizinhos; Farida e sua protetora Virgínia; Kindzu e Farida. Os núcleos temáticos - a busca de identidade, a violência da guerra civil, o conflito de raças, a exploração sexual da mulher negra pelo patrão branco - são gerados nesse espaço de atravessamentos. É o que se pode apreender ao examinar os três encontros principais da narrativa: o encontro do ônibus, dos cadernos e do navio. A configuração desses encontros como centros de expansão e de tensão narrativa leva à retomada de algumas formulações já apresentadas.

Os episódios que constam da sequência inicial do filme, não correspondem ao início da narrativa que é possível assistir. De início não se sabe que o homem caído ao lado de sua mala se chama Kindzu e é um personagem importante da trama. $O$ encontro do ônibus é apenas o encontro de uma morada, à beira da mata e supostamente longe das minas subterrâneas encravadas no solo. 
Graças a esse machimbombo ${ }^{3}$ atravessado na estrada, os personagens cruzam diferentes mundos: o mundo dos mortos, dos vivos, da guerra, do sonho e da utopia. Do ponto de vista da montagem, o ônibus atua na composição dos enquadramentos: ao transportar os cadáveres carbonizados para fora para enterrá-los, descobrem o corpo ainda quente de um outro morto - dono de uma mala que sobreviveu aos saques. Nessa mala encontram comida, roupas, uma bola e os cadernos de Kindzu. Ainda que incendiado, foi o encontro do ônibus que transportou os personagens para a aventura interior de cada um.

Na cena inicial, o homem agonizante não parece ter sido passageiro do ônibus, daí sua mala ter permanecido intacta na mata. Para o velho Tuahir a comida era o mais importante de seu conteúdo; analfabeto, os cadernos eram apenas papel para acender a fogueira. Para o menino, em cuja memória os signos da escrita tinham sido preservados da ação do esquecimento, os cadernos despertaram seu interesse pela leitura, abrindo caminho para entrar em uma outra história.

Os cadernos estavam escritos em forma de diário em que se conta a história de um homem em meio à guerra. Na cena inicial do filme, a guerra é indicializada pelo ônibus incendiado e pelos corpos carbonizados. Aqui, ela emerge nos conflitos narrados por Kindzu, o jovem pescador que anotara na abertura de seus escritos:

Começo a escrever esses escritos para espantar o medo de enlouquecer. As lembranças que tenho parecem difíceis de ordenar, como se quisessem fugir da minha cabeça. O tempo passava com mansa lentidão quando chegou a guerra. No princípio só escutavamse as vagas novidades acontecidas ao longe. Depois os tiroteios foram chegando mais perto e o sangue foi enchendo o nosso medo. (Prata, 2010, 7"35'-8"10')

A leitura é o elo que introduz outro cenário: Kindzu que regressa do mar e se dirige para a aldeia, primeiro para sua casa, depois, para o armazém de Assame, com os cadernos nas mãos. Lá, uma cena de furto desencadeia a conversa entre Kindzu e Assame:

A: Não gosto nada de pretos, Kindzu.

$\mathrm{K}$ : Então, gosta de quem, dos brancos?

A:Também não.

K: Já sei, gosta dos indianos.

A: Não, gosto de homens que não têm raça como você (Prata, 2010, $\left.10^{\prime \prime} 21^{\prime}-10^{\prime \prime} 34^{\prime}\right)$.

3 Denominação do ônibus em língua local. 
Cada cena se torna núcleo de um conjunto temático que repercute na história: aqui é a discussão do racismo e do confronto que sustenta a guerra civil entre os povos. Na sequência, os bandos atacam não só o bar, como também a aldeia de Kindzu exterminando sua família. Seu choro cria uma onda sonora que reverbera no ônibus em que o menino lê os cadernos, em um atravessamento espaço-temporal que potencializa o espaço acústico-ressonante e sua força dramatúrgica.O tempo escoa visualmenteno espaço pela reverberaçãodo choro. Muidinga ao ler o episódio, também começa a chorar e os prantos se misturam, ainda que as lágrimas estejam em corpos separados no tempo de espaço.

A incidência de movimentos ressonantes começa a mostrar sua importância: antes era o barulho do mar ressoando na mente do menino; aqui é o pranto; em seguida, a primeira lembrança de Muidinga de sua vida pregressa: os barulhos dos meninos na escola. As memórias escritas de Kindzu ativam a memória de Muidinga e se fazem presença. Nas cenas em que Tuahir e Muidinga conversam enquanto se deslocam pela mata é da história de Kindzu que falam.

Conforme a leitura dos cadernos avança, as personagens ganham corporeidade e começam a "participar" das conversas, dos sonhos e da vida de Tuhair e Muidinga. Os cadernos transportam os personagens para uma outra narrativa e, nesse sentido, cumprem um papel explosivo de deslocamento. Como afirma Muidinga: "Cada vez que lemos os cadernos ele nos leva para outro lugar". (Prata, 2010, 25"23'). Surge nele também o desejo de buscar um outro lugar: o homem e o menino retomam a estrada e partem em busca do caminho do mar. Como eles estão no coração da mata, muitos são os obstáculos a serem vencidos.

Voltemos aos cadernos e à história de Kindzu.

O desespero pela perda da família leva Kindzu a partir pelo mar. Navega durante vários dias, sem rumo, até encontrar um navio encalhado: nele se abriga Farida que, depois de vencer o constrangimento da presença do estranho visitante, narra sua história e justifica porque ela optara por viver foragida no navio. Com a morte da mãe, Farida fora acolhida pela protetora D. Virgínia. Aprendera a ler e se tornara amada pela família, mas nem isso, impediu que o marido da gentil senhora se aproveitasse dela. Grávida, foge para a aldeia. A fuga silenciosa, a falta de coragem para revelar a identidade do pai da criança, os maus tratos por ter gerado um filho mulato, a tornam incapaz de ser mãe e a criança é dada para ser criada em uma missão. Doze anos se passaram e nasceIhe a necessidade de recuperar o filho Gaspar. Kindzu promete trazer de volta seu menino e parte em uma nova viagem, colocando na mala algumas roupas, comida, uma bola e os cadernos. 
A história de Farida desperta em Muidinga uma hipótese sobre sua identidade: seria ele o filho de Farida? O menino toma a hipótese como provável e o que justifica sua crença é o barulho do mar que ressoa em sua cabeça, como se pode ler em sua decisão: "Eu vou até Farida... É o som do mar que eu oiço... eu preciso saber o que isso significa". (Prata, 2010, 38"47'-38"59'). Partem. Andam muito pela mata e novos episódios acontecem: caem em uma armadilha e encontram Siqueleto, um homem que ficara sozinho em uma aldeia e quer enterrar gente como sementes para repovoar o local. Conseguem escapar e, de volta à estrada, encontram um homem de circo com a filha amarrada de modo que seu corpo se ondule como o de uma cobra. Por último, um cabrito aprisionado escapa, entra para a mata, pisa em uma mina, e morre em uma explosão. Depois de muito andarem, descobrem que andaram em círculos, pois estão de volta para o ônibus.

Na leitura dos cadernos, Muidinga entra no episódio em que Kindzu está a caminho da aldeia de MateMate e reencontra Assame, agora viúvo e paraplégico. Descobre a casa de D. Virgínia e depois parte em busca de Tia Eusina, protetora de Farida, que Ihe confidencia onde se encontra Gaspar. Kindzu segue em busca de Gaspar e quando sua missão está prestes a terminar, o bando que assaltara o ônibus, o encontra e o mata. Consegue ver o menino que se aproxima com o homem e pronuncia com um fio de voz, o nome de Gaspar. Este seria o episódio inicial da narrativa em um ordenamento cronológico.

Quando, pela segunda vez, Tuahir e Muidinga tentam encontrar o caminho para o mar, novamente voltam para o ônibus. Na terceira e última tentativa, seguem pelos trilhos de trem e Tuahir relembra seus dias de chefe de estação. A cena é tomada por imagens sonoras de trens chegando e partindo: agora, o centro acústico do som acusmático é a mente de Tuahir. $O$ encontro de uma mulher com um bebê faz com que Muidinga comece a imaginar sua história com sua mãe. O caminho, contudo, não leva ao mar e eles se veem de volta ao ônibus. Revoltado, o menino esmurra o ônibus e cai ajoelhado no chão; seu carrinho-barco de brinquedo desliza e Muidinga sorri para a ideia que acaba de lhe despertar a mente. Começa a cavar o solo, como muitos povos africanos fazem em época de seca, sob o olhar interrogante deTuahir. Cava freneticamente, em silêncio, até que o fio d'água começa a brotar. Logo o filete se torna um jorro e transborda, invadindo a estrada e se torna um rio caudaloso. O ônibus tomado pelas águas começa a se mover, ao que Tuahir observa: "Não somos nós que estamos a andar, é a estrada". (Prata, 2010, 1:15"14'). A água toma conta da estrada, mas não é o movimento das águas que se ouve, mas sim o barulho do trem deslizando suavemente sobre o curso do rio, agora transformado em caminho que leva ao encontro do mar. Tuhair pressente a morte e pede para o 
menino lançar seu corpo no mar. Morre quando o menino avista o navio onde estava Farida.

\section{Ressonâncias metalinguísticas transformadas em metanarrativas e metalepses}

O sonar das ondas que parecia apenas memória acústica de Muidinga dimensiona fios narrativos que repercutem uns nos outros, o que se observa na construção dos planos de ação traduzida nos vários deslocamentos em que uma história se projeta do interior de outra e todas se entrecruzam em algum ponto de modo que uma se transforma na metalinguagem da outra. Um jogo que Muidinga percebe na leitura dos cadernos mas somente nós, os espectadores, conseguimos articular do ponto de vista de uma topologia com entrecruzamentos no tempo e espaço.

Os sons acusmáticos como o ruído do mar que povoa a cabeça de Muidinga, o som do trem que embala a mente de Tuahir ou o choro de Kindzu que atravessa a mata e o tempo e ressoa dentro do ônibus realizam movimentos de cortes sincrônicos uma vez que aproximam temporalidades distintas. Por meio de tais possibilidades estéticas a narrativa se desloca da terra para o mar, da guerra para os espaços de liberdade, do passado para o presente. A única constante é o impulso que leva à transformação de um pelo outro. Nisso reside o centro da representação estética que cria um território de convivência e de fronteiras. As metalinguagens se abrem para metarrativas e metalepses.

No filme, mais do que no livro, a trama é conjugada por atritos entre circularidades de núcleos concêntricos de narrativas, cujos vetores de ação se deslocam em torno das forças gravitacionais de seu centro, mas em reverberação no espaço de sua circunscrição. Com isso, as trajetórias sempre ressoam deixando rastros que se ligam como em circuitos que ao reverberarem uns esbarram em outros, com diferentes forças de atração e de repulsa. Os cadernos guardam potencialmente todo o jogo ficcional da narrativa que se desdobra entre a escrita e a leitura e, ao se materializar na voz e na vida do menino, faz do espectador-leitor um cúmplice e tecelão dos fios dispersos no emaranhado das tramas que se cruzam. Tudo isso, a partir da enunciação que transforma a própria voz narrativa em discurso enunciado na tela.

Se na introdução de nossa análise, se anunciou o encaixe como processo fundamental da construção narrativa é chegada a hora de expandir tal entendimento e avançar para a análise da plasticidade discursiva do espaço ressonante que se manifesta nas diferentes performances da voz, quando projetadas no espaço da tela e percebidas pelo espectador. 
O encontro da mala, a descoberta dos cadernos e a consequente leitura das memórias de Kindzu, criam o jogo da ficcionalidade discursiva que se desenvolve enquanto metanarrativa. Uma narrativa voltada para ela mesma, quer dizer, assiste-se a um filme cujas chaves da trama - vestígios de trajetórias a que se referiu anteriormente - se encontram no interior de um episódio elaborado no interior da narrativa e, portanto, um fato semiótico: a leitura do texto escrito. Também, o encadeamento dos eventos passados, não apenas aqueles conservados pela memória de Kindzu, mas aqueles narrados por Farida, são postos em sequência quando equacionados pela leitura. Com isso, a diacronia é alcançada graças à ação da leitura que se movimenta operando cortes sincrônicos. Paradoxalmente, o conjunto da articulação não é fruto da composição que corre pela tela, mas depende unicamente do trabalho de percepção da mente interpretadora do espectador.

As metanarrativas assim organizadas funcionam segundo um mecanismo de tradução em diferentes níveis. No filme Terra sonâmbula o desdobramento tradutório flui através da leitura dos cadernos de Kindzu. A geração de um discurso dentro do outro; o deslocamento que embaralha o fio narrativo; a interação entre espaço audiovisual e espaço, que se constitui na percepção do espectador, são os traços fundantes da metanarratividade, criada enquanto jogo ficcional.

Percebe-se um paradoxo. Se Kindzu é narrador da história de Gaspar e Farida, Muidinga só pode ser leitor de sua própria história; e, do mesmo modo, se os espectadores, ao interagir com ambas as histórias se tornam agentes do jogo ficcional, uma vez que lhes cabe recodificar cinética e audiovisualmente as metanarrativas em confronto, então o espaço narrativo rompeu seus próprios limites.

Quando Kindzu justifica sua necessidade de escrever à necessidade de tanto dar vazão a seus sonhos, quanto de liberar as lembranças que querem saltar de sua mente, ele anuncia algo bem mais complexo do que uma liberação de energias criativas. O que ele acaba produzindo é todo um trabalho de transgressão do espaço narrativo, configurado como produção de uma voz narradora. $\mathrm{O}$ que o cinema fez foi traduzir plasticamente tal transgressão, sobretudo, porque é condição do cinema traduzir audiovisual e cineticamente os espaços expandidos da memória, traduzir em articulação acústica a vocalidade, que se manifesta em potência na memória, seja dos indivíduos seja da cultura.

De discurso indireto, a narrativa audiovisual torna-se voz em discurso direto, uma sobreposta à outra, sem distinção, construindo um espaço heterogêneo de alternância e de geratividade: um discurso que nasce no interior de outro discurso, assim como o filme que nasce da escrita da voz e das 
articulações audiovisuais a que o espectador assiste na tela. A partir daí, cresce o questionamento: em que medida o espectador não é igualmente participante da cena, uma vez que tem acesso à realização visual e acústica que se realiza enquanto percepção? Afinal, é o espectador que ouve o som acusmático do sonar das ondas, do choro de Kindzu e do trem imaginário de Tuahir. Também somos nós, os espectadores que ouvimos as últimas palavras sussurrantes de Kindzu, chamando pelo menino, dizendo seu nome: Gaspar, antes de morrer na mata, ao lado de sua mala com seus sonhos e a poesia de seus cadernos.

Tal apagamento das demarcações precisas dos limites narrativos com consequente ampliação das fronteiras que abrem caminhos para outras relações tornam a narrativa um solo poroso, sujeito a deslizamentos. Ao se assentarem sobre tal processo construtivo as metanarrativas criam condições favoráveis ao desenvolvimento do princípio construtivo que, em literatura, se consagrou como metalepse ${ }^{4}$. Gerard Genette, que observou a passagem do uso da metalepse da retórica para a narrativa, imprimiu coerência ao procedimento ao constatar o intercâmbio entre os diferentes níveis do universo diegético, metadiegético e extradiegético (Genette, 2004; Martelo, 2015) dissolvendo os prováveis elos sustentados pelo pacto da representação. No caso específico do cinema, a irredutibilidade do espaço topográfico, ocupado pelo espectador e aquele constituído como filme, potencializa sua heterogeneidade, enquanto espaço projetado na tela.

Segundo Rosa Maria Martelo "a metalepse pode produzir o efeito de aproximar do mundo do leitor/espectador um dos níveis de realização contemplados na obra deixando o outro (ou outros) à distância" (Martelo, 2015, p. 286). Pode-se dizer então: Em Terra sonâmbula, já não é a adaptação da obra literária para o cinema o que movimenta o foco de interesse da análise, mas sim o processo de tradução intersemiótica em que o plano enunciativo é estratificado para se constituir enquanto processo cinético-audiovisual que, vincula as esferas da criação, da representação e da percepção. Os limites entre autor, personagem e espectador se diluem e suas ações passam a se implicar mutuamente.

Se o princípio construtivo fundante da metanarrativa é a reflexão sobre sua própria construção, sem dúvida que há nela uma ruptura com a noção de estrutura encerrada em si mesmo e uma abertura para relacionamentos com diferentes intervenções composicionais, inclusive para interpretantes do pensamento crítico. Com isso, os procedimentos de auto-reflexividade

4 Jogo semântico em que se toma o antecedente pelo consequente (ou vice-versa). No filme, referese à antecipação do final da trama pela leitura dos cadernos. 
da metanarrativa não deixam de funcionar como um espaço de ressonância, um espaço qualificado pela temporalidade e pelo movimento das imagens audiovisuais - matriz epistêmica de estudo na cultura audiovisual.

\section{Considerações finais}

Iniciou-se as análises examinando o vínculo da dramaturgia audiovisual ao espaço cinemático produzido pela transdução da luz operada pelo cinematógrafo. O campo experimental da teoria foi desenvolvido com a análise do universo sonoro do filmes O Bandido da luz vermelha, de Rogério Sganzerla, e das metalepses metanarrativas de Terra sonâmbula, de Teresa Prata. Em ambos os casos, a qualidade sonoro-acústica extrapolou a sonoridade das cenas ou das músicas incidentais, projetando um espaço dramático pulsante de distintas formações sensoriais e, por isso mesmo, de efeito interativo com mutualidade dialógico audiovisual. Viu-se, por conseguinte, as imagens sonoro-acústicas se investirem de espacialidades capazes de extravasarem a tela de projeção e tomarem conta do ambiente sensorial da sala e da mente dos espectadores. Os espaços ressonantes pulsantes que extravasam a estrutura interna da cena, ganham o ambiente externo e dialogam com o discurso interior, com a consciência e com a memória dos espectadores e da cultura. Um espaço que não se constitui apenas de procedimentos estruturais internos de composição - caso dos planos derivados da perspectiva óptica da imagem visual que se reproduz nas lentes de câmeras (de fotografia, de cinema, de vídeo e nas câmeras digitais) - mas da associação de gravação sonora de ruídos, vozes, músicas com a consequente reverberação acústica da projeção em salas de exibição com a distribuição de canais e fontes de reprodução.

Entende-se, por conseguinte, que as imagens audiovisuais criadas pelo cinema exploram algumas possibilidades que nem sempre são consideradas, quando são analisadas estritamente pelo viés da visualidade fotográfica e pictórica dos planos visuais e de sequências. Ainda que o ponto de partida sejam os planos de luz, o processo de transdução operado pelo cinematógrafo é bem mais diversificado, uma vez que a projeção resulta tanto em movimento quando em reverberação sonto-acústica. Com tais atributos, o espaço acústicoressonante aqui delineado não se confunde com a perspectiva óptica da imagem visual, ainda que a imagem audiovisual se constitua pela composição de ambos.

Face a tais considerações se pode afirmar que as imagens audiovisuais adquirem o estatuto de agentes criadores de um espaço qualificado pela temporalidade e pelo movimento. De atributo técnico, o epíteto "imagem em movimento" torna-se episteme da imagem audiovisual e, consequentemente, objeto distintivo do estudo na cultura audiovisual inaugurada pelo cinema. 


\section{REFERÊNCIAS}

BERNADET, Jean-Claude. Universo sonoro. In: Ocupação Rogério Sganzerla. São Paulo: Itaú Cultural, 2010. Vídeo: Youtube. Disponível em: https://www.youtube. com/watch?v=JDYPYV14LCw. Acesso em: 04/01/2017.

O vôo dos anjos. São Paulo: Brasiliense, 1990.

CHION, Michel. L’audio-vision. Paris: Nathan, 1996.

COUTO, Mia. Terra sonâmbula. São Paulo: Companhia das Letras, 2015.

GENETTE, Gérard. Métalepse. De la figure à la fiction. Paris: Seuil, 2004.

MARTELO, Rosa M. Livros, filmes, metalepses. In: ROWLAND, Clara; BÉRTOLO, José (orgs). A escrita do cinema: ensaios. Lisboa: Documenta, p. 277-289, 2015.

MCLUHAN, M.; PARKER, H. O espaço na poesia e na pintura através do ponto de fuga. São Paulo: Hemus, 1975.

McLUHAN, M.; POWERS, B. R. Exploraciones en el espacio visual y el acústico. In: La aldea global. Barcelona: Gedisa, 1996.

SCHAEFFER, Pierre. Traité des objects musicaux. Paris: Seuil, 1967.

SEBEOK, Thomas. Comunicação. In: Comunicação na era pós-moderna. Rector, Mônica ; Neiva, Eduardo (orgs). Petrópolis: Vozes, 1997.

SEIÇA, ALVARO. Transdução: Processos de Transferência na Literatura e Arte Digitais. Lisboa: Humus, 2017. Disponível em: http://www.ensino.uevora.pt/ mclc/. Acesso em: 12/09/2017.

STERNE, Johnathan. The audible past. Cultural origins of sound reproduction. DuKe: Duke University Press, 2003.

O BANDIDO da luz vermelha. Direção, Roteiro e Música: Rogério Sganzerla. Produção: José da Costa Cordeiro; José Alberto Reis; Rogério Sganzerla. Intérpretes: Paulo Vilaça; Luiz Linhares; Helena Ignes; Pagano Sobrinho; Roberto Luna. Fotografia: Peter Overbeck; Carlos Ebert. Montagem: Sylvio Renoldi. Sonoplastia: Edmar Agostinho. Narração: Helio Aguiar; Mara Duval. Sonorização: Odil Fono Brasil. Laboratório de Imagem: Líder - São Paulo. Brasil, 1968, 1h32min, p/b.

TERRA sonâmbula. Argumento e Direção: Teresa Prata. Produção: Filmes de Fundo. Produtores: Antonio e Pandora da Cunha Telles. Intérpretes: Nick Lauro Teresa; Aladino Jasse; Hélio Fumo; Ilda Gonzalez; Laura Soveral. Fotografia: Dominique Gentil. Direção de Arte: Caroline Alder. Música: Alex Goretzki. Figurinos: Isabel Peres. Portugal-Moçambique, 2007, 96min., cor. 
Recebido em: 14/9/2017

Aceito em: 10/11/2017

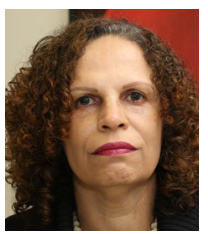

Dados da autora:

Irene de Araújo Machado | irenemac@uol.com.br

Universidade de São Paulo (USP)

Professora Livre-Docente do PPG em Meios e Processos Audiovisuais, Escola de Comunicações e Artes, USP.

Pesquisadora CNPq-PQ 1D.

PPG em Meios e Processos Audiovisuais da Escola de Comunicações e Artes da USP

Endereço da autora:

Av. Prof. Lúcio Martins Rodrigues, 443 - Butantã

05508-020 - São Paulo (SP) - Brasil 